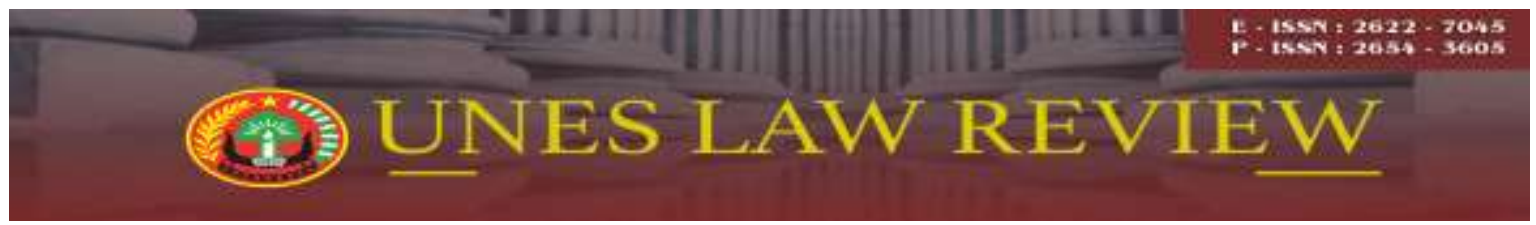

Email: uneslawreview@gmail.com

Online: http://review-unes.com/index.php/law

Volume 2, Issue 1, September 2019

\title{
KAJIAN KRIMINOLOGI TERHADAP TAWURAN YANG BERPOTENSI TINDAK PIDANA OLEH PELAJAR DI KOTA PADANG
}

\author{
${ }^{1}$ Budi Rahmat, ${ }^{2}$ Fitriati \\ ${ }^{1}$ Anggota POLRI, Kepolisian Daerah Sumatra Barat \\ E-mail : budirahmatwatukosek41@gmail.com \\ 2 Program Magister Ilmu Hukum, Universitas Ekasakti, Padang \\ E-mail : fitriati@univ-ekasakti-pdg.ac.id
}

\begin{abstract}
Various efforts were made by the regional government and law enforcement officials to tackle brawls between students in the city of Padnag, but there was no formulation of countermeasures that could eradicate fights between students in the city of Padang. This research is a legal research with analytical descriptive specifications with a normative juridical approach supported by an empirical juridical approach. The results showed that the causes of brawls among adolescents who have the potential for criminal acts in the city of Padang include internal factors, which are quite low self-control, lack of religious values in themselves and want to see their existence. Furthermore External Factors include egoistic community, because of friend's invitation, because of a sense of solidarity, because of school selfishness and because of pressure and invitation from school alumni. Efforts made to combat the occurrence of fights between adolescents who have the potential for criminal acts in the city of Padang include preventive efforts, including through family channels such as supervision and family attention to other family members, school paths in the form of lightning pesantren, character and other education etc. and routine supervision. Repersive measures such as School actions to provide disciplinary penalties, legal processes by the police and conduct acts of arrest and coaching by the Civil Service Police Unit.
\end{abstract}

Kata Kunci: Tawuran, Tindak Pidana, Pelajar, Kriminologi

\section{PENDAHULUAN}

S.R. Sianturi (78:1996), mengatakan bahwa tindakan yang dilarang adalah (melakukan) suatu kenakalan yang karenanya dapat menimbulkan kerugian atau keresahan. Mengenai pengertian kenakalan di sini, dalam undang-undang ini tidak ditentukan. Karenanya diadakan batasan-batasan yang dengan demikian dapat dipahami, perbuatan apa saja yang dapat digolongkan sebagai kenakalan.Sehubungan karena kenakalan remaja tersebut berpotensi terjadinya tindak pidana maka perlu dilakukan upaya-upaya 
pencegahan. Upaya pencegahan dapat dilakukan dengan mengetahui faktor penyabab remaja melakukan kenakalan atau perbuatan melawan hukum tersebut.

Anak-anak dan remaja yang melakukan kejahatan itu pada umumnya kurang memiliki kontrol-diri, atau justru menyalahgunakan kontrol-diri tersebut, dan suka menegakkan standar tingkah-laku sendiri, di samping meremehkan keberadaan orang lain. Kejahatan yang mereka lakukan itu pada umumnya disertai unsur-unsur mental dengan motif-motif subyektif, yaitu untuk mencapai satu objek tertentu dengan disertai kekerasan. Pada umumnya anak-anak dan remaja tersebut sangat egoistis, dan suka sekali menyalahgunakan dan melebih-lebihkan harga dirinya.

Untuk mencari faktor yang lebih esensial dari bentuk tindak pidana/ kejahatan yang dilakukan secara sempurna kedudukan ini dapat diartikan dengan faktor kejahatan yang timbul secara ekstern (faktor luar) maupun intern (faktor dalam) dari pelaku tindak pidana kejahatan seseorang. Secara implisit berbagai faktor dapat dijadikan sebagai sistem untuk merumuskan kejahatan pada umumnya ataupun kejahatan anak pada khususnya. Berbeda dengan seseorang anak atau pun dalam melakukan kejahatan, tampak bahwa faktor-faktor apapun yang di dapat pada diri anak dan remaja yang jelas semuanya tidak terstruktur maupun disikapi terlebih dahulu.

Dalam fakta-fakta yang terjadi di Kota Padang, tidak jarang ditemui anak-anak remaja terlibat dalam perbuatan yang tidak sesuai dengan norma-norma yang berlaku ditengah masyarakat. Sebut saja tawuran antar remaja, pemerasan, membawa senjata tajam, konvoi-konvoi dengan kendaraan bermotor dan perbuatantercela lainnya.

Melihat realitas yang demikian maka ada korelasi kuat antara lingkungan, ekonomi dan faktor lainnya yang berkembang ditengah masyarakat yang mempengaruhi prilaku kaum remaja di Kota Padang. Kota Padang termasuk kota besar di Sumatera Barat yang aksesbilitas informasi, teknologi dan industrialisasi lebih mudah untuk didapatkan dibanding dengan kota-kota lainnya d Sumatera Barat, sehingga perkembangan arus globalisasi dan westernisasi rentan mempengaruhi prilaku kaum remaja jika tidak adanya upaya-upaya pencegahan yang harus segera dilakukan.

Berdasarkan latar belakang pemikiran yang telah dipaparkan di atas, maka rumusanpermasalahan adalahApakah penyebab tawuran antar pelajar yang berpotensi terjadinya tindak pidana di Kota Padang dan Bagaimanakah upaya yang dilakukan untuk 
menanggulangi terjadinya tawuran antar pelajar yang berpotensi tindak pidana di Kota Padang.

\section{METODE PENELITIAN}

Spesifikasi penelitian adalah deskriptif analisis,dengan metode pendekatanyuridis normatif dan pendekatan yuridis empiris. Jenis data yang digunakan adalah data sekunder dan data primer. Data sekunder diperoleh dari studi dokumen dan data primer diperoleh dari lapangan. Teknik pengumpulan data pada data sekunder dilakukan dengan studi kepustakaan dan pada data primer dengan wawancara dan observasi. Data yang diperoleh kemudian dianalisa secara kualitatif serta disajikan dengan deskriptif analitis.

\section{HASIL DAN PEMBAHASAN}

\section{Penyebab Tawuran Antar Pelajar Yang Berpotensi Terjadinya Tindak Pidana Di Kota Padang}

Secara psikologis, perkelahian yang melibatkan pelajar usia remaja digolongkan sebagai salah satu bentuk kenakalan remaja (juvenile deliquency). Kenakalan remaja, dalam hal perkelahian, dapat digolongkan ke dalam 2 (dua) jenis delikuensi yaitu situasional dan sistematik.

Pada delikuensi situasional, perkelahian terjadi karena adanya situasi yang "mengharuskan" mereka untuk berkelahi.Keharusan itu biasanya muncul akibat adanya kebutuhan untuk memecahkan masalah secara cepat.Sedangkanpada delikuensi sistematik, para pelajar yang terlibat perkelahian itu berada di dalam suatu organisasi tertentu atau geng. Di sini ada aturan, norma dan kebiasaan tertentu yang harus diikuti anggotanya, termasuk berkelahi. Sebagai anggota, mereka bangga kalau dapat melakukan apa yang diharapkan oleh kelompoknya. Tak bisa dipungkiri, kenakalan remaja belakangan ini semakin mengkhawatirkan saja. Nyaris setiap hari, kita disuguhkan berita kenakalan remaja yang sudah melewati batas kewajaran. Bukan saja mengarah kepada kriminalitas biasa.

Kota Padang sebagai salah satu kota besar di Sumatera Barat dengan keaneragaman dan heterogennya masyarakat yang berdomisili di kota tersebut telah menimbulkan berbagai persoalan, tidak kecuali permasalahan sosial di tengah-tengah masyarakat termasuk tawuran antar remaja. 
Ada faktor yang menyebabkan remaja/anak melakukan tindakan kriminal. Faktor internal yang mempengaruhi perilaku kenakalan remaja, merupakan aspek kepribadian yang berasal dari dalam diri anak remaja seperti konsep diri yang rendah. Penyesuaian sosial serta kemampuan menyelesaikan masalah yang rendah, sikap yang berlebihan serta pengendalian diri yang rendah. Konsep diri adalah bagaimana individu memandang dirinya sendiri meliputi aspek fisik dan aspek psikologis.Aspek fisik adalah bagaimana individu memandang kondisi tubuh dan penampilannya sendiri. Sedangkan aspek psikologi adalah bagaimana individu tersebut memandang kemampuan-kemampuan dirinya, harga diri serta rasa percaya diri dari individu tersebut. Salah satu yang menjadi faktor penyebab dari pelajar yang melakukan tindak pidana atau perbuatan kriminal atau tawuran adalah faktor sifat dari pelajar itu sendiridi kota Padang.

Penelitian menunjukkan bahwa remaja-remaja yang melakukan kenakalan tersebut adalah karena Pengendalian diri yang cukup rendah.Pengendalian diri yang rendah dalam artian remaja tersebut mudah terpengaruh oleh kondisi-kondisi lingkungan, sehingga disaat ada dorongan-dorongan negatif yang muncul dari dalam diri mereka sebagai akibat rangsangan kondisi sosial lingkungan, mereka akan melakukan perbuatan tersecela, bahkan mendorong terlibat perbuatan kriminal.

Kurangnya nilai-nilai religius dalam diri mereka.Faktor ini sangat erat kaitannya dengan pengendalian diri seorang remaja, karena dengan kurangnya nuansa religius dalam diri mereka maka remaja akan cenderung untuk berpikir dengan jalan pintas tanpa filterisasi yang cukup dalam diri mereka. Mereka ingin membuktikan bahwa mereka sama sekali tidak terkontrol dalam konteks keimanannya. Ketika nilai religius kurang dalam diri mereka, maka akan menimbulkan ketidakmampuan remaja dalam melakukan penyesuaian sosial atau beradaptasi terhadap nilai dan norma yang ada di dalam masyarakat, kondisi ini dibuktikan dengan ketidakmampuan anak/remaja dalam melakukan penyesuaian sosial seperti maraknya perilaku kriminal oleh remaja yang tergabung dalam geng motor, membolos serta aksi mereka yang selalu berhubungan dengan tindakan kriminal seperti memalak anak-anak sekolah lain, memaksa remaja lain untuk ikut bergabung dengan geng mereka serta ada beberapa anggota yang pernah melakukan tindakan kriminal pencurian motor. Hal tersebut menunjukkan ketidakmampuan remaja-remaja tersebut dalam 
berperilaku adaptif, mereka memiliki kemampuan penyesuaian sosial serta kemampuan menyelesaikan masalah yang rendah, sikap.

Ingin melihatkan eksistensi diri.Dalam konteksi teori, remaja berada dalam tahapan perkembangan yang merupakan transisi dari masa kanak-kanak menuju masa dewasa, dengan tugas perkembangan untuk pencarian jati diri, tentang seperti apa dan akan menjadi apa mereka nantinya. Dalam kondisi ini maka anak-anak ini berada dalam tahap perkembangan identity vs identity confusion. Bila berhasil maka anak akan mencapai tahap perkembangan dipenuhinya rasa identitas diri yang jelas, dan sebaliknya anak akan mengalami kebingungan identitas bila gagal dalam melewati tahap perkembangan ini. Ingin melihatkan eksistensi diri dan pengakuan lingkungan menjadi bagian dari faktor internal remaja melakukan perbuatan pidana, termasuk tawuran antar remaja. Ketika sekelompok remaja ingin melihatkan eksistensi dirinya pada kelompok remaja yang lainnya, maka mereka akan cenderung untuk menonjolkan bahwa kelompok mereka adalah kelompok yang terbaik dan merasa paling hebat dari kelompok lainnya. Berawal dari rasa unggul diri ini akan memancing timbulkan konflik antara remaja tersebut, yang lebih dikenal dengan tawuran.

Perlu juga dipahami bahwa pada masa ini anak-anak dan remaja juga sedang berada dalam periode strom dan stress, karena pada tahap perkembangan ini mereka bukan lagi anak-anak yang selalu bergantung pada orang tua dan juga bukan orang dewasa yang sepenuhnya mandiri dan otonom, anak-anak ini masih tergantung pada orang tua terutama dalam hal ekonomi di mana semua kebutuhannya masih harus dipenuhi oleh orang tuanya.

Faktor eksternal yang besar pengaruhnya terhadap anak dengan kriminalitas adalah keluarga dalam hal ini kondisi lingkungan keluarga. Kondisi lingkungan keluarga pada masa perkembangan anak dan remaja telah lama dianggap memiliki hubungan dengan munculnya perilaku antisosial dan kejahatan yang dilakukan oleh remaja. Beberapa penelitian mengenai perkembangan kenakalan dan kriminalitas pada remaja, ditemukan bahwa tindak kriminal disebabkan adanya pengalaman pada pengasuhan yang buruk.Ketiga pola asuh orang tua terhadap anak yaitu pola asuh autoritarian, permissive dan univolved ini menyebabkan seorang anak berperilaku anti sosial.

Milieuatau lingkungan sekitar tidak selalu baik menguntungkan bagi pendidikan dan perkembangan anak. Lingkungan sehari-hari menambah pengaruh perkembangan jiwa 
si anak serta kepribadiannya.Karena memang sudah merupakan naluri manusia untuk berkumpul dengan teman-teman untuk bergaul. Tapi pergaulan akan menimbulkan efek yang baik dan tidak baik pula. Yang tidak baik akan mendorong si anak terperosok kepada anak yang tidak mendapat bimbingan orangtua atau tidak memperdulikan orangtuanya sama sekali. Jiwa para remaja itu amat labil.Jika mereka mendapatkan pengaruh buruk, maka mereka dengan mudah terpengaruh perilaku buruk tadi.Lalu terbentuklah gang-gang remaja berandalan dengan jalan menyebar teror di tengah lingkungan, selalu membuat onar dan berkelahi sepanjang hari.Dan juga untuk memenuhi segala ambisi dan kebutuhan itu mereka tidak segan-segan melakukan pencurian, penodongan, perkelahian, penggarongan, pengeroyokan, perkosaan dan pembunuhan.

Dalam belajar sosial, fungsi role model sangat penting. Namun pada saat role model yang tampil di media-media elektronik maupun sosial mempertontonkan perilaku negatif yang bertentangan dengan nilai dan norma masyarakat, misalnya klip musik, iklan, film atau sinetron menampilkan adegan seks bebas, perselingkuhan, kekerasan, transgender, pembunuhan dan kriminalitas. Hal itu dapat menjadi faktor pendorong Anak/Remaja untuk mencoba-coba atau menirunya. Selain itu, perilaku negative yang terus menerus ditampilkan di media massa, juga dapat dianggap sebagai perilaku yang benar secara sosial dan dan menjadi model peran yang ditiru oleh Anak/Remaja.

Beberapa faktor eksternal yang mendorong remaja di Kota Padang melakukan tawuran antar remaja sebagai berikut egoistik komunitas, ajakan Teman, karena Adanya Rasa Solidaritas, egoistik sekolah, karena tekanan dan ajakan alumni sekolah.

\section{Upaya Yang Dilakukan Untuk Menanggulangi Terjadinya Tawuran Antar Pelajar Yang Berpotensi Tindak Pidana di Kota Padang}

Barda Nawawi Arief (42:2005), mengutip pendapat G.P. Hofnagels dalam upaya penanggulangan kejahatan yaitu melalui cara:

1. Penerapan hukum pidana (criminal law application)

2. Pencegahan tanpa pidana (prevention without punishment)

3. mempengaruhi pandangan mengenai kejahatan dan pemidanaan lewat media massa (influencing views of society in crime and punsihment/mass media)

Upaya penanggulangan kejahatan secara garis besar dapat dibagi 2 (dua), yaitu lewat jalur "penal" (hukum pidana) dan jalur "non penal" (bukan/di luar hukum pidana). Dalam pembagian G.P. Hofnagels diatas, upaya-upaya yang disebut dalam butir (2) dan (3) 
dapat dimasukkan dalam kelompok "non penal". Penal policy dapat diartikan dengan kebijakan hukum pidana atau politik hukum pidana.

Penanggulangan tawuran pelajar yang melibatkan anak tentu berbeda dengan penanggulangan kejahatan yang dilakukan oleh orang dewasa, mengingat anak tidak sama dengan orang dewasa. Anak memiliki sistem penilaian kanak- kanak yang menampilkan martabat anak sendiri dan kriteria norma sendiri, sebab sejak lahir anak sudah menampakan ciri- ciri dan tingkah laku karakteristik yang mandiri, memiliki kepribadian yang khas dan unik.

Terhadap penanggulangan tawuran pelajar, upaya preventif dapat dilakukan melalui sekolah, keluarga serta pihak kepolisian. Terhadap penangulangan tawuran melalui upaya represif dapat dilakukan melalui sekolah, pihak kepolisian, hingga penuntutan dan pemeriksaan sidang. Upaya preventif pertama yang dapat dilakukan melalui diantaranya seperti, sekolah memaksimalkan jam pelajaran, mengadakan kegiatan-kegiatan non akademik yang melibatkan siswa, disiplin dari guru, serta kordinasi guru dan orang tua.

Sekolah menjadi tempat awal mula pelajar menemukan "lingkaran" pertemanan yang dikenal dengan istilah "geng", sehingga peran sekolah untuk mencegah terjadinya perbuatan tawuran sebenarnya sangat besar. Kebanyakan sekolah, lebih memilih untuk tidak ikut campur dalam geng pelajar di sekolahnya, karena eksistensi geng tersebut sudah dimulai dari sangat lama, sehingga menurut sekolah akan sulit untuk memutus mata rantai aktivitas perekretutan geng. Kurangnya perhatian maupun sikap disiplin dari sekolah terhadap siswanya sangat mungkin dapat memicu terjadinya aksi tawuran, seperti misalnya aktivitas sekolah yang minim jam pelaksanaan proses belajar mengajarnya, sehingga menyebabkan pelajar memiliki lebih banyak waktu luang untuk berkumpul dengan gengnya, maupun sikap acuh tak acuh sekolah yang menganggap tawuran, jika terjadi diluar jam sekolah maka hal tersebut bukan menjadi urusan sekolah, melainkan urusan masing-masing siswanya, atau sekolah yang menganggap tawuran adalah bagian dari proses pembentukan jati diri, sehingga tidak menjadi masalah antar siswa melakukan hal tawuran, sepanjang tidak menggangu hubungan antar sekolah.

Mengantisipasi aksi tawuran tersebut, Tim gabungan Satuan Polisi Pamong Praja (Satpol PP) Kota Padang bersama Satpol Pamong Praja Sumatera Barat, melakukan patroli gabungan di sekitaran Kota Padang. Sebelum patroli, tim gabungan Satpol PP telah 
mendapat informasi bahwa akan dilaksanakannya tawuran di beberapa lokasi yang sudah menjadi target sasaran Satpol PP Kota Padang. Patroli demi mencegah aksi tawuran, khususnya pada bulan Ramadhan dilakukan dari pukul 01.00 hingga pukul 04.00 menjelang sahur. Dari hasil patroli yang dilakukan, kadangkala Sat Pol PP menemukan belasan senjata tajam berbagai jenis yang diduga akan digunakan sebagai senjata dalam melakukan aksi tawuran. Setelah ditangkap, mereka digiring ke Markas Komando (Mako) Satpol PP Kota Padang untuk didata serta diberikan pembinaan agar tidak terjadi lagi hal yang sama.

Satuan Polisi Pamong Praja Kota Padang, akan terus meminimalisir tawuran yang akan terjadi di Kota Padang dan dalam hal ini peran masyarakat sangat dibutuhkan dalam upaya meminimalisir tawuran tersebut. Barkaitan tindakan yang sudah diberikan kepada remaja yang ditangkap karena tawuran antara lain memanggil orang tua mereka dan membuat surat pernyataan sebagai tindakan awal.

Pemerintah Kota Padang telah berusaha untuk mengantisipasi dan menangkal kenakalan remaja dengan menggalakkan kembali ke surau.Mengajak remaja kembali ke surau atau masjid dipandang menjadi solusi yang bagus untuk meminimalisir kenakalan remaja yang terus berkembang akhir-akhir ini.Pemerintah Kota Padang menekankan remaja perlu dibimbing dan mendalami ilmu agama.Untuk itu menurutnya, sebagai langkah awal hal itu adalah dengan menekankan setiap siswa SD dan SMP bisa hafal Al Quran. Selain program kembali ke surau, pemerintah Kota Padang terus menggalakkan program "Maghrib Mengaji”. Setiap anak diimbau untuk mengaji mulai dari setelah salat magrib hingga isya.

Penanggulangan kenakalan remaja, khususnya tawuran pelajar pada dasarnya tidak dapat dilepaskan dari kajian kriminologi, apabila dibiarkan tanpa adanya pembinaan dan pengawasan yang tepat, secara terpadu oleh semua pihak, maka gejala kenakalan anak ini akan menjadi tindakan-tindakan yang mengarah kepada tindakan yang bersifat kriminalitas, karena tindakan tawuran pelajar sudah menjurus kepada perbuatan pidana seperti menyebabkan luka ringan,berat, sampai kepada tindakan menghilangkan nyawa orang lain, paling tidak upaya penanggulangan tindak pidana dibedakan menjadi dua yaitu upaya preventif (nonpenal) dan upaya represif (penal). 
Setiap orang tua wajib membekali anak-anaknya dengan pendidikan agama. Hal ini karena pendidikan agama merupakan pendidikan dasar yang banyak mengajarkan etika serta moral-moral kehidupan. Sehingga ketika anak-anak tak dibekali dengan pendidikan agama sedari kecil, maka tentu saja akan berakibat buruk pada perilakunya. Anak remaja bisa saja memiliki moralitas yang rendah dan melakukan kenakalan-kenakalan tanpa dipikirkan terlebih dahulu.

Pesatnya informasi yang dengan mudah diakses oleh anak remaja dapat mempengaruhi perilaku keseharian. Bahkan anak remaja akan dengan mudah terpengaruh perilaku pornografi. Dengan kemampuan penyampaian informasi yang dimiliki internet, pornografi pun merajalela.Dengan sekali sentuh, anak remaja dapat menyaksikan adegan pornografi yang seharusnya hanya konsumsi orang dewasa.Tentu saja hal ini berpengaruh buruk pada perilakunya.Kondisi ini memicu hasrat remaja yang tak terkontrol sehingga menyebabkan seks di luar nikah (seks bebas), bahkan perkosaan.

Tawuran pelajar merupakan salah satu perbuatan anak yang dapat dikategorikan sebagai kenakalan remaja (juvenile deliquency), yang menjadi tradisi mengakar di kalangan pelajar.Meningkatnya aksi tawuran pelajar sendiri dapat meningkatkan angka tindakan kriminal.Tidak sedikit aksi tawuran terjadi baik yang melibatkan sekolah-sekolah swasta maupun negeri.

Jika pelaku sudah berulang kali melakukan aksi tawuran maka dapat di berikan upaya penal (represif)dengan dikenakan Pasal 170 KUHP atau Pasal 351 KUHP yang mengacu pada undang-undang sistem peradilan pidana anak. Karena mengingat usia ratarata pelajar masih tergolong dalam usia anak, sehingga kasus tersebut hanya dapat diproses melalui sistem peradilan pidana anak.

Selama pencegahan tawuran pelajar hanya dilakukan melalui imbauan dan penyuluhan, selama itu pula tawuran pelajar akan terus terjadi. Tawuran pelajar merupakan bentuk kekerasan khas karena para pelakunya tidak bertindak atas dasar politik atau ekonomi, tetapi untuk identitas kebanggaan.Maka pendekatan yang sifatnya pengajaran moral cenderung tidak digubris. Pendekatan yang bersifat penyuluhan yang datang dari orangtua, guru, atau pihak-pihak lain dianggap para pelajar sebagai orang luar yang tidak tahu apa-apa tentang persoalan "dendam antarsekolah" yang telah berlangsung turun- 
temurun. Mau tidak mau, kebijakan yang perlu diambil harus bersifat perombakan sistem yang lebih represif.

Pelaku tawuran antarpelajar sulit ditindak dengan pasal-pasal pidana. Pelaku tawuran hanya bisa dijerat hukum pidana jika tawuran itu menimbulkan korban luka ataupun meninggal dunia, misalnya dari aksi putar-putar gir, ada yang berakibat korban luka atau tewas. Tidak ada tindak pidana, tidak bisa dipidanakan, makanya cuma dilakukan peringatan atau pembinaan. Tawuran merupakan suatu bentuk tindak pidana, karena pada umumnya tawuran melanggar Pasal 170, 351, 355, 358 KUHP yang merupakan bentuk kejahatan, dan Pasal 489 KUHP yang merupakan pelanggaran. Mengenai penerapan pasalpasal tersebut, haruslah dilihat dulu unsur-unsur yang ada di dalam peristiwa tawuran tersebut.

Dalam hal penegakan hukum masalah tawuran antarpelajar, tidak ada pertanggungjawaban pidana jika pelaku merupakan seorang anak, karena tindakan tersebut hanyalah sebuah kenakalan saja, maka untuk penyelesaian kasus perkelahian massal (tawuran) antarpelajar hanya dapat digunakan system peradilan anak, maupun upaya diversi Diversi adalah sebuah upaya untuk mencegah anak masuk ke dalam sistem peradilan anak.Upaya diversi hanya dapat dilaksanakan atas dasar izin korban dan keluarganya, serta kesediaan dari pelaku dan keluarganya.

Lebih spesifik bagaimana cakupan Pasal 170 dan Pasal 358 KUHP berkenaan dengan peristiwa tawuran (perkelahian beramai-ramai) dan bagaimana ketentuan tentang penyertaan tindak pidana dalam kaitannya dengan Pasal 170 dan Pasal 358 KUHP. Penuntutan terhadap peristiwa tawuran (perkelahian beramai-ramai) yang mengganggu ketertiban umum/meresahkan masyarakat, baik yang mengakibatkan terjadinya korban (luka, luka berat, mati, atau kerusakan barang) maupun yang tidak mengakibatkan korban, lebih tepat dikenakan Pasal 170 KUHP. Jika tawuran menimbulkan korban luka berat atau mati barulah dapat dituntut berdasarkan Pasal 358 KUHP. Peristiwa tawuran pada umumnya melibatkan cukup banyak orang sehingga akan selalu dikaitkan dengan ketentuan tentang penyertaan melakukan tindak pidana.

Kenakalan remaja sering menjadi pemberitaan, termasuk tawuran antara remaja. Di Kota Padang juga sering terjadi tawuran antar remaja, bahkan Walikota Padang pernah menyatakan kekhawatirannya mengenai kenakalan remaja pada tahun 2017. Beliau 
menyebutkan kenakalan remaja di Kota Padang sudah kelewat batas. Kenakalannya sudah "allahurabbi" dan membuat orang tua geleng-geleng kepala. Saya banyak mendapat laporan.Setiap malam minggu (Sabtu malam) terjadi tawuran. Ada gengnya, nama gengnya macam-macam, seram semua, hampir setiap akhir pekan para remaja melakukan aksi tawuran massal.

Tindakan preventif yang sudah dilakukan oleh Pemerintah Kota Padang melalui sekolah adalah dengan adanya pesantren setiap bulan ramadhan serta kurikulum yang berbasis karakter. Hal ini tentu sangat membantu mengurangi dan mencegah terjadinya tawuran antara remaja.Disisi lain, Pemerintah Kota Padang juga sudah menggalakkan beberapa program yakni "kembali ke surau" dan magrib mengaji". Namun program ini tidak akan efektif jika perna keluarga kurang maksimal. Karena keluarga merupakan bagian utama dari pembentukan karakter seorang anak.

Upaya preventif lain yakni melalui kepolisian, polisi sudah selayaknnya mengetahui wilayah-wilayah yang rawan untuk melakukan tawuran. Melakukan razia pada lokasi-lokasi tertentu dan di jadwal-jadwal yang berpotensi untuk terjadi tawuran sangat diperlukan, hal ini terbukti efektif karena beberapa rencana pelajar untuk melakukan tawuran bisa saja dibatalkan karena sudah diketahui oleh polisi, disamping itu, untuk menghindari aktivitas tawuran polisi dapat melakukan sosialisasi kepada para pelajar di sekolah-sekolah untuk menghindari pebuatan tawuran, karena akibat dari tawuran, seorang pelajar bisa saja dikenai ancaman pidana.

Upaya represif yang dapat dilakukan pihak sekolah pembinaan kepada siswa atau pemanggilan oleh guru, koordinasi sekolah dan pihak kepolisian, serta pemberitahuan ke orang tua. Upaya represif pertama yakni melalui sekolah, dalam hal sekolah mengetahui siswa sekolahnya melakuka tawuran, sekolah akan melakukan pemanggilan kepada siswa yang terbukti melakukan tawuran,hukuman yang dapat diberikan sekolah tidak bersifat pembalasan atau dapat menimbulkan efek jera, karena sanksi yang diberikan biasanya hanya berbentuk nasehat dari guru, hal ini hanya dilakukan jika sekolah mengetahui siswanya ikut melakukan tawuran.

Upaya represif kedua yakni melalui kepolisian, dalam hal polisi berhasil mengamankan pelajar yang terlibat tawuran, sanksi yang diberikan polisi sifatnya berupa pengamanan atas pelajar pelaku tawuran di kantor polisi, hukuman yang diberikan bisa 
berbentuk hukuman fisik, mulai dari perintah untuk melakukan push-up hingga menampar atau memukul pelajar tersebut, dan sanksi baru selesai diberikan dalam hal sudah ada perwakilan dari keluarga yang menjemput anak pelaku tawuran. Sayangnya, sanksi yang diberikan oleh polisi ini sifatnya hanya menimbulkan efek jera sementara dan pelaku tidak memahami manfaat dari pemberian sanksi tersebut, menurut pelaku, hukuman fisik sifatanya hanya mengakibatkan lelah secara fisik. Sehingga seharusnya, diharapkan sanksi yang diberikan oleh pihak kepolisian memang bersifat mendidik dan dapat menimbulkan efek jera bagi pelaku tawuran. Koordinasi dari kepolisian dengan pihak sekolah baru terjadi apabila polisi menghubungi sekolah dari pelaku tawuran, namun hal ini jarang dilakukan jika tawuran dilakukan tanpa identitas sekolah, koordinasi yang dilakukan hanya antara orang tua dan polisi, tidak ada pemberian informasi kepada sekolah.

Bentuk koordinasi antara sekolah dan kepolisian dilakukan dalam bentuk pengiringan pelajar hingga sampai di rumah setelah kegiatan belajar mengajar telah usai, perwakilan dari sekolah dan perwakilan dari polisi biasanya akan melakukan pengawalan terhadap kelompok pelajar yang merupakan geng pelaku tawuran pelajar. Meskipun hal ini dilakukan, namun lagi-lagi pelaku tawuran pelajar dapat menyiasatinya, karena seperti yang penulis singgung sebelumnya, tawuran masih dapat dilakukan diluar jadwal sekolah.

Peran yang dilakukan oleh Satuan Polisi Pamong Praja.Hal ini terbukti telah dilakukannnya beberapa kali penindakan oleh Sat Pol PP untuk menjaga ketentraman dan ketertiban masyarakat.Sehingga tidak jarang Sat Pol PP menjaring para pelajar nakal yang tertangkap di beberapa tempat, seperti perempatan jalan, jalur hijau dan tempat khalayak umum lainnya.Sanksi yang diberikan berupa pembinaan terhadap remaja dimaksud dan pemanggilan orang tuanya yang kemudian dibuat perjanjian.

Pelaku tawuran pelajar dapat dituntut dengan pasal 170 KUHP tentang pengeroyokan karena tawuran pelajar dilakukan secara beramai-ramai.Selain itu juga bisa digunakan pasal-pasal tentang kejahatan terhadap nyawa yaitu pasal 378 KUHP, 339 KUHP, dan 340 KUHP, atau pasal-pasal tentang penganiayaan seperti pasal 351 KUHP, $352 \mathrm{KUHP}$, dan pasal $354 \mathrm{KUHP}$, tergantung fakta yang terungkap dipersidangan. Atau dapat mengacu pada Undang-Undang No. 23 Tahun 2002 Tentang Perlindungan Anak jika pelaku merupakan anak, dan Undang-Undang Darurat No. 2 Tahun 1991 yang 
didalamnya mengatur tentang senjata tajam atau senjata api, karena tidak jarang pelaku tawuran juga menggunakan alat-alat berbahaya dalam aksinya.

\section{PENUTUP}

Penyebab tawuran antar pelajar yang berpotensi terjadinya tindak pidana di Kota Padang meliputi faktor internal yakni pengendalian diri yang cukup rendah, kurangnya nilai-nilai religius dalam diri mereka dan ingin melihatkan eksistensi diri. Selanjutnya Faktor Eksternal antara lainegoistik komunitas, karena ajakan teman, karena adanya rasa solidaritas, karena egoistik sekolah dan karena tekanan dan ajakan alumni sekolah. Kedua, Upaya yang dilakukan untuk menanggulangi terjadinya tawuran antar remaja yang berpotensi tindak pidana di Kota Padang meliputi upaya preventif dan upaya represif. Upaya preventif antara lain melalui jalur keluarga seperti pengawasan dan perhatian keluarga terhadap anggota keluarga lainnya, jalur sekolah berupa pesantren kilat, pendidikan berarakter dan lainnya sebagainya serta jalur kepolisian berupa patroli dan pengawasan scara rutin. Selanjutnya melalui upaya repersif seperti tindakan tegas oleh Sekolah untuk memberikan hukuman disiplin bagi sisiwa yang terlibat tawuran, penindakan atau proses hukum oleh kepolisian serta melakukan tindakan penangkapan dan pembinaan oleh Satuan Polisi Pamong Praja.

\section{DAFTAR PUSTAKA}

\section{Buku Teks:}

Barda Nawawi Arief, Bunga Rampai Kebijakan Hukum Pidana, Citra Aditya Bakti, Bandung, 2005.

S.R. Sianturi, Asas-Asas Hukum Pidana di Indonesia dan Penerapannya, Alumni AhaemPetehaem, Jakarta, 1996.

\section{Peraturan Undang-Undang:}

Kitap Undang-Undang Hukum Pidana (KUHP).

Undang-Undang Dasar Repubulik Indonesia Nomor 23 Tahun 2002 Tentang Perlindungan Anak. 